\title{
New data on Acicula benoiti (Bourguignat, I 864) (Gastropoda Architaenioglossa Aciculidae) and description of A. hierae n.sp. from Marettimo Island (Sicily, Italy)
}

\author{
Fabio Liberto ${ }^{*}$,Agatino Reitano², Roberto Viviano ${ }^{3} \&$ Ignazio Sparacio ${ }^{4}$ \\ ${ }^{1}$ Via del Giubileo Magno 93, 90015 Cefalù, Italy; e-mail: fabioliberto@yahoo.it \\ ${ }^{2}$ Natural History Museum, Via degli Studi 9, 97013 Comiso (Ragusa), Italy; e-mail: tinohawk@yahoo.it \\ ${ }^{3}$ Via Michele Cipolla 106, 90123 Palermo, Italy; email; roberto.viviano@outlook.com \\ ${ }^{4}$ Via Principe di Paternò 3, 90144 Palermo, Italy; e-mail: edizionidanaus@gmail.com \\ ${ }^{*}$ Corresponding author
}

\begin{abstract}
New morphological and distributional data on Acicula benoiti (Bourguignat, 1864) (Gastropoda Architaenioglossa Aciculidae) in Sicily are provided. In addition, A. hierae n. sp. from Marettimo Island (Egadi Islands, N-W Sicily, Italy) is here described. The new species is characterized by conic-subcylindrical shape, with obtuse apex, thick parietal callus; well developed angular tooth; external peristomal varix raised, rounded, and anteriorly and posteriorly delimited by simple line.
\end{abstract}

KEY WORDS Acicula; land snails; Sicily; biodiversity; taxonomy; island endemism.

Received 12.08.2020; accepted 21.11.2020; published online 30.12.2020

\section{INTRODUCTION}

The small operculate prosobranch gastropods of the genus Acicula W. Hartmann, 1821 are widespread in the western Palaearctic Region (MolluscaBase, 2020). Currently, in Sicily only a species is known, A. benoiti (Bourguignat, 1864) (Boeters et al., 1989; Bodon et al., 1995; Reitano et al., 2009, 2012; Bank \& Ramos, 2017; MolluscaBase, 2020).

Field surveys carried out in recent years in Sicily and surrounding islands allowed us to increase knowledge on the genus Acicula in this region.

In this paper, new data on $A$. benoiti and the description of a new species from Marettimo Island, A. hierae n. sp., are provided.

\section{RESULTS}

Empty shells and live specimens were collected in the field on sight on the soil and under the rocks or by sieving litter and soil. Observations on ecology of these organisms were made directly in the field, and in the laboratory where living snails were bred in plastic boxes. These little terrariums $(5 \mathrm{~cm} \times 6 \mathrm{~cm} \times 5 \mathrm{~cm})$ contained a thin layer of autochthonous topsoil, litter of native plant and small fragments of carbonate rock; the humidity was kept high and the contents were changed twice a week. The empty shells have been immersed for less than two minutes in hydrogen peroxide $\left(\mathrm{H}_{2} \mathrm{O}_{2}\right)$ and than in sodium hypochlorite $\mathrm{NaClO}$, and subsequently cleaned with water and a flat bristle brush. Dry shells have been studied regarding size, colour, morphology, sculpture.

In order to study and illustrate genital organs, some specimens were drown in water and fixed in $80 \%$ ethanol. The bodies were isolated from the shells and dissected under the Optika stereomicroscope using a very fine pointed scalpel, scissors and needles. Photos were taken with a Canon EOS 100D 
camera and Laowa $2.5 \times 5$ Xultra macro. Specimens were also examined uncoated under a Tescan Vega 2 LMU Scanning Electron Microscope in Low Vacuum modality to investigate tube micromorphology. All images were acquired at the Department of Biological, Geological and Environmental Sciences (University of Catania). Height and maximum diameter of the shell along with some parts of genitalia were measured (in millimeters) by a digital gauge. Taxonomical references are based on the checklist of the land and freshwater Gastropoda of Europe (Bank \& Ramos, 2017; MolluscaBase, 2020).

The materials used for this study are deposited in the following Museums and private collections: F. Liberto collection, Cefalù, Italy (CL); Museo Civico di Zoologia, Rome, Italy (MCZR); A. Reitano collection, Tremestieri Etneo, Catania, Italy (CR), I. Sparacio collection, Palermo, Italy (CMS); R. Viviano collection, Palermo, Italy (CV).

ABBREVIATIONS AND ACRONYMS. D: maximum diameter; ex: specimen/s; E: eye; F: foot; $\mathrm{H}$ : shell height; LWH: height last whorl; m: meter/s; mm: millimeter/s; O: operculum; P: penis; sh: shell/s; T: tentacle.

\section{RESULTS}

\section{Systematics}

Phylum MOLLUSCA Cuvier, 1795

Classis GASTROPODA Cuvier, 1795

Subclassis CAENOGASTROPODA Cox, 1960

Ordo ARCHITAENIOGLOSSA Haller, 1890

Superfamilia CYCLOPHOROIDEA Gray, 1847

Familia ACICULIDAE Gray, 1850

Genus Acicula W. Hartmann, 1821

Acicula benoiti (Bourguignat, 1864) Figs. 1-4, 7 htpp://zoobank.org:act:34A7EC67-59ED-489D9ABB-733F074D2DB5

Pupula lineata - Calcara, 1845: 34 - nel fiume Oreto, presso il ponte delle Grazie, alla Guadagna, ed a Mondello - (non Draparnaud, 1801)

Acme lineata - Benoit, 1859: Pl. 5, Fig. 33 (not Draparnaud, 1801)

Acme benoiti - Bourguignat, 1864: 218-219 - Sicilie

Acme benoiti - Paladilhe, 1868: 323 - Sicilie, environs de Palerme
Acme benoiti - Westerlund, 1871: 424 - Sicilien

Acme lineata - Benoit, 1875: 154 - alle sponde del fiume Oreto, sotto il ponte delle Grazie (not Draparnaud, 1801)

Acme benoiti - Schacko, 1875: 147-148, Pl. 5, Fig. 4 - Sicilien

Acicula benoiti - Pfeiffer, 1876: 5 - Sicilia

Acme benoiti - Paulucci, 1879: 192-194 - Sicilia

Acme benoiti - Kobelt, 1881: 131 - Sicilien

Acme benoiti - Paulucci, 1881: 223 - Sicilia, Corleone

Acme lienata - Benoit, 1882: 149-150 - campagne di Palermo, alle sponde del fiume Oreto, sotto il ponte delle Grazie (not Draparnaud, 1801)

Acme (Acicula) benoiti - Westerlund, 1885: 101 Sicilien bei Palermo

Acme lineata var subdiaphana - De Gregorio 1895: 205 - Fiume Oreto (Palermo)

Acme benoiti - Kobelt in Rossmaessler, 1896: 10, P1. 182, Fig. 1150 - in der Umgebung von Palermo Acme (Auricella) benoiti - Kobelt \& Mollendorff, 1897: 74 - Sicilien

Acme benoiti - Kobelt, 1898: 298 - Sicilien

Acme (Auricella) benoiti - Kobelt, 1908: 166 Palermo

Pupula benoiti - Hesse, 1920: 88 - Palermo

Acicula benoiti - Gittenberger \& Boeters, 1977a: 218-219

Acicula benoiti - Boeters et al., 1989: 27, 28, 30 32, 34, 54, 72 Figs. 21, 25, 26, 54 - Sizilien, in den Provinzen Palermo und Siracusa

Acicula benoiti - Bodon et al., 1995: 20 - Sicilia

Acicula benoiti - Cossignani \& Cossignani, 1995: 38, 39 - Sicilia

Acicula cfr. benoiti - Reitano et al., 2009: 184, Fig. 4a-b - Melilli, Grotta Palombara, in ambiente ipogeo

Acicula benoiti - Liberto et al., 2010: 38, Fig. 24 Sicilia

Acicula benoiti - Reitano et al., 2012: 558-559, Fig. 9 - Palermo, Grotta Conza

Acicula benoiti - Welter-Schultes, 2012: Syracuse

Acicula benoiti - Cossignani \& Cossignani, 2020: 18, 19 - Palermo

Acicula benoiti - MolluscaBase 2020 - Sicily

EXAMINED MATERIAL. Italy, Sicily, Palermo, Fiume Oreto presso Ponte della Grazia, 38 04'44.6”N 1319'22.9'E, 80 m, 18.XI.1990, 6 sh, (CMS 1258/6); Palermo, Grotta Molara, 38 8'47.30”N 13ำ'17.58”'E, 117 m, 12.VIII.2002, 2 sh (CR) 

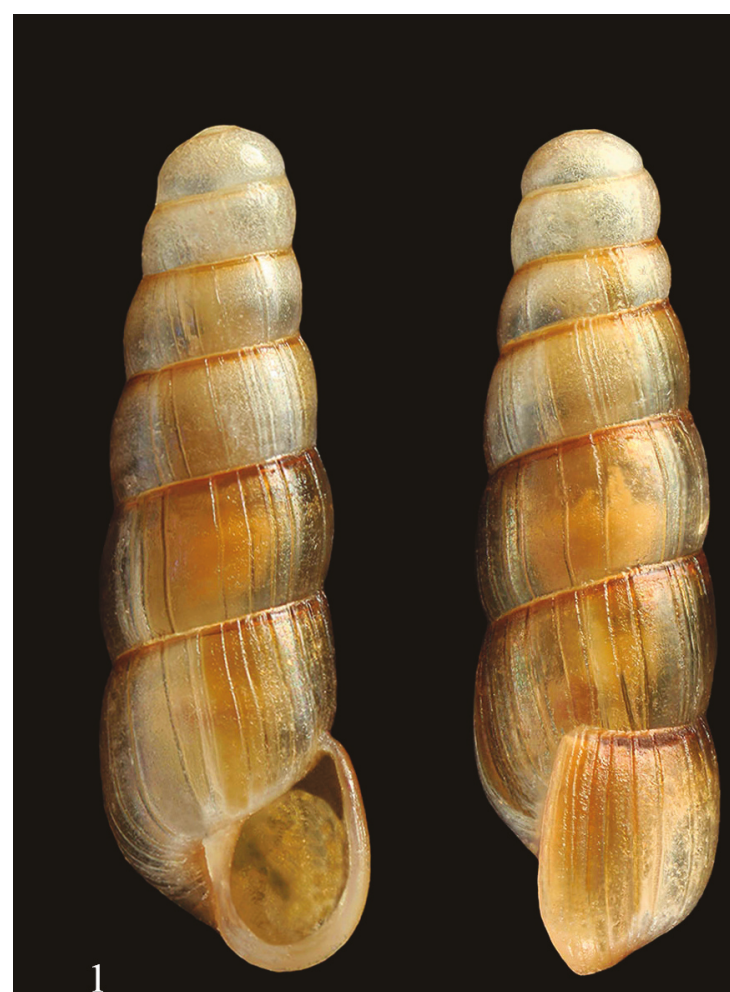

2
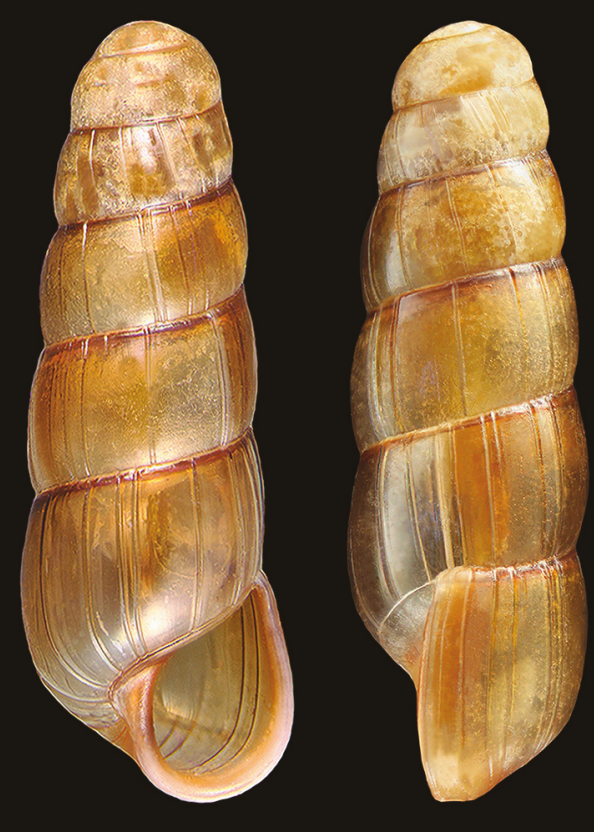

\section{(1)}

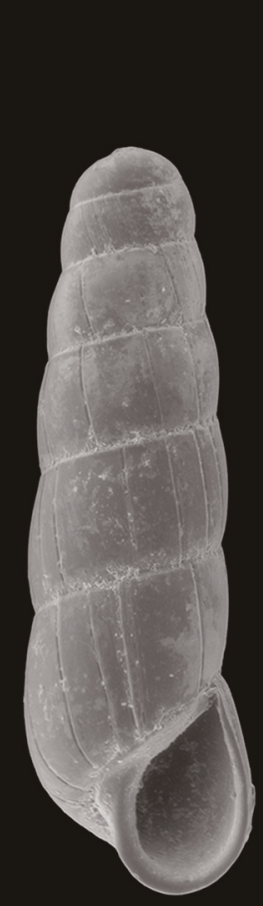

3
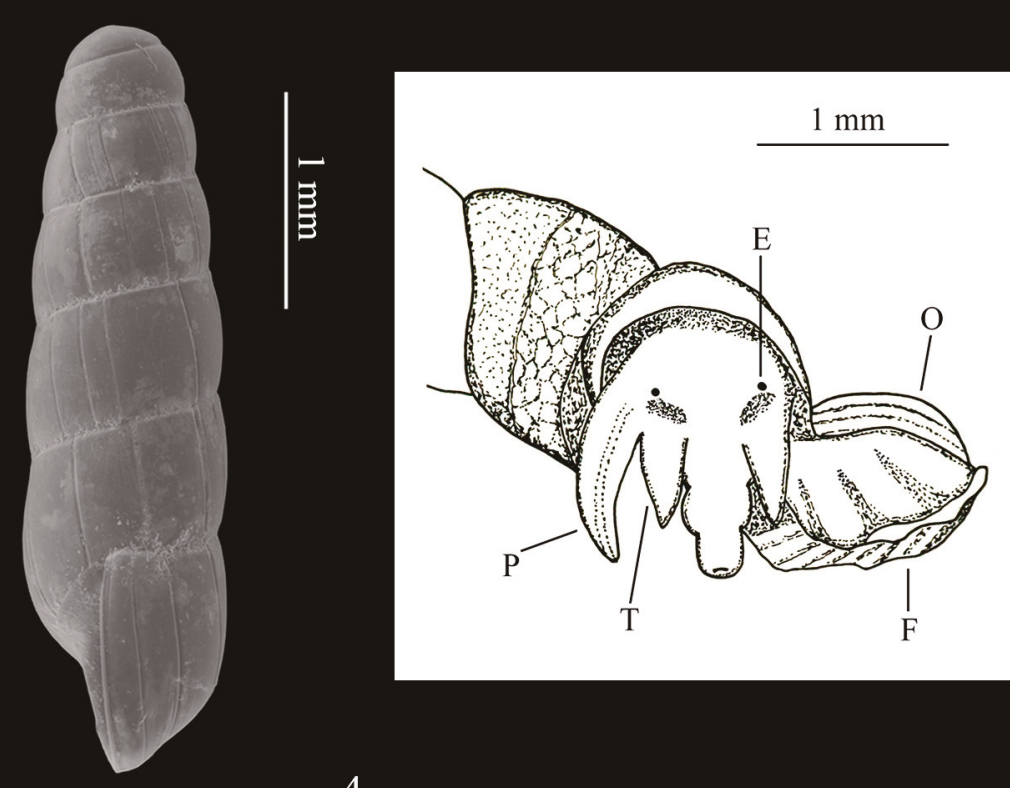

4

Figures 1-4. Acicula benoiti. Fig. 1: Italy, Sicily, Palermo, Fossa della Garofala, H: 4.1 mm, with soft part. Fig. 2: Idem, H: 3.8 mm. Fig. 3: Italy, Sicily, Palermo, Grotta Molara, H: 3.4 mm, SEM photo. Fig. 4: Body of Acicula benoiti from Palermo, Fossa della Garofala. 
(Fig. 5); Gratteri, Pizzo Giurafelle, 37' $58^{\prime} 19^{\circ} \mathrm{N}$ 1400'08'E, 767 m, 14.X.2007, 9 sh (CL 31623170); Gratteri, Pizzo Giurafelle, $37^{\circ} 58^{\prime} 21^{\prime \prime} \mathrm{N}$ 1400'05"E, 700 m, 19.I.2008, 8 sh (CL 33803387); Carini, Monte Columbrina, Grotta Za Minica, 3809'29'N 1313'43”E, 18.VIII.2008, 7 sh (CL 3542-3548); Gratteri, Vallone tra Rocca Stefana e Pizzo Giurafelle, 3758'54'N 1400'20'E, 650 m, 2.XI.2008, 2 sh (CL 4083-4084); Palermo, Grotta Conza, 38¹1'14”N 1316'42'”E, 190 m, legit S. Giglio, V.2012, 1 sh (CL 17325); Gratteri, Monte Dipilo, Pizzo Dipilo, 3756'55'N 1358'47'E, 1134 m, 17.XI.2013, 2 sh (CL 62606261); Palermo, Bellolampo, Pizzo Capra, east slope, $38^{\circ} 07^{\prime} 58^{\prime \prime} \mathrm{N} \quad 13^{\circ} 16^{\prime} 39.5^{\prime \prime} \mathrm{E}, 355 \mathrm{~m}$, 03.V.2015, 1 sh (CV); Palermo, Monte Gallo, La Fossa, 38¹2'02'N 1317'59'”, 92 m, IV.2016, 1 ex (CV); Palermo, Monte Castellaccio, 3809’36”N 13०15'50”'E, 800/850 m, 26.V.2016, 4 sh (CV); Palermo, Inserra, Cozzo San Croce, $38^{\circ} 08^{\prime} 57^{\prime} \mathrm{N}$ 1317'37''E, 400 m, 07.VI.2016, 1 sh (CV); Palermo, Monte Pellegrino, Pizzo Monaco, 38 10'11.5'N 1321'33'E, 485 m, 13.VI.2016, 4 sh (CV RV19-0411); Palermo, Pizzo Manolfo, 38॰10'13”N 1316’25”'E, 615 m, 16.X.2016, 1 sh (CV); Altavilla Milicia, Grotta Mazzamuto, 3801'24.3”'N 13³3'45”'E, 195 m, 01.XII.2018, 1 ex (CV); Cinisi, Monte Pecoraro, Cima Bosco Tagliato, north slopes, $38^{\circ} 10^{\prime} 08^{\prime \prime} \mathrm{N} 13^{\circ} 07^{\prime} 35^{\prime \prime E}$, 450/520 m, 10.II.2019, 13 sh (CV); Palermo, Monte Pellegrino, Addaura, 38 $11^{\prime} 08^{\prime \prime} \mathrm{N} 13^{\circ} 20^{\prime} 43^{\prime \prime} \mathrm{E}$, 145/155 m, 06.IV.2019, 9 sh (CV); Palermo, Fossa della Garofala, $38^{\circ} 06^{\prime} 04^{\prime \prime} \mathrm{N} 13^{\circ} 20^{\prime} 40^{\prime \prime} \mathrm{E}, 50 \mathrm{~m}$, 24.IV.2019, 26 sh (CV) (Fig. 2); Palermo, Fossa della Garofala, $38^{\circ} 06^{\prime} 04^{\prime \prime N} 13^{\circ} 20^{\prime} 40^{\prime \prime} \mathrm{E}, 50 \mathrm{~m}$, 24.IV.2019, legit R. Viviano, 3 sh (CMS 5251/3) (Figs. 1, 4); Palermo, Monte Pellegrino, Roccia dello Schiavo, west slopes, 38 $09^{\prime} 40.7^{\prime \prime} \mathrm{N}$ 1320'44”'E, 5 sh, 110-150 m, 20.V.2016 (CV RV19-0225); Palermo, Monte Gallo, La Fossa, $38^{\circ} 12^{\prime} 32.6^{\prime} \mathrm{N} \quad 13^{\circ} 17^{\prime} 29.6$ 'E, 170-185 m, 30.V.2020, 4 sh (CV).

DESCRIPTION. Shell (Figs. 1-3) dextral, elongate, conic-subcylindrical with obtuse apex, H: 3-4.6 mm, D: 1-1.3 mm; LWH: 1-0.9 mm, glassy and sub-transparent, light brown in color with a thin subsutural darker brown band. Spire consisting of $6 \frac{1}{2}-7 \frac{1}{2}$ slightly convex whorls; suture shallow. The last whorl is $22-27 \%$ of the total shell height. External surface of teleoconch smooth, with irreg- ular spaced radial grooves, 10-20 in penultimate whorl. Aperture oval-pyriform, wide; large columellar callus; peristoma edge almost straight in lateral view; evident angular tooth; external peristomal varix swollen; in lateral view it has the same width troughout its lenght, more flat above and swelling in the basal part where it appears without clear demarcation.

Operculum semi-transparent, very thin, paucispiral with semi-central nucleus; the outer face shows growth lines (10-12) higher in the central part; the inner face is smooth.

White body, two thin blackish spots at the base of the tentacles, black eyes, foot with whitish sole; whitish visceral sac with yellowish spots mainly gathered on the penultimate whorl. The margin of the mantle partially covers the head; two tentacles wider at the base, and with rounded apex, shorter in the males and thinner and more elongated in the females. The penis is conic elongated, subelliptical in cross section, slightly curved, slightly enlarged at the base and tapered near apex which is flattened, about a third longer than the tentacles; it is crossed by a groove over the entire ventral surface up to the apex (Fig. 4).

Distribution And Biology. Acicula benoiti is an endemic Sicilian species. According to the data in the present work, it is widespread especially in north-western Sicily: Mountains of Palermo, Madonie and Sicani Mountains, while no data are known for the mountains of Trapani (Fig. 7).

It is also reported for south-eastern Sicily (Syracuse province) by Boeters et al. (1989) and WelterSchultes (2012). The report from Grotta Palombara, Syracuse, is only for comparison (Reitano et al., 2009: A. cfr. benoiti). Fiorentino et al. (2004) report $A$. benoiti for Marettimo island, but we believe that this record should be referred to new species that we describe below.

Acicula benoiti has been found in the bedding at the base of trees and large bushes of the Mediterranean scrub, even in partially naturalized crops (Quercus ilex L., Euphorbia dendroides L., Pistacia lentiscus L., Fraxinus ornus L., Rhamnus alaternus L., Laurus nobilis L., Celtis australis L., Morus alba L., Hedera helix L., Acanthus sp., Citrus spp., Rubus sp.). It lives at the base of shady limestone walls, in endogeous environment, under stones and debris, always in damp and shady environments. 
Status And COnSERvation. Acicula benoiti is "Vulnerable", according to Cuttelod et al. (2011) and Neubert et al. (2019).

REMARKS. Acicula benoiti was described by Bourguignat (1864) for Sicily ("Habite la Sicile") based on specimens received by Benoit ("in Specim. Ab illo missis, in the year 1857"). The Sicilian author (Benoit, 1882) had collected these specimens "nelle campagne di Palermo, alle sponde del fiume Oreto, sotto il ponte delle Grazie" [in the countryside of Palermo, on the banks of the Oreto river, under the Ponte delle Grazie] reiterating that the specimens described by Bourguignat came from these localities.

Boeters et al. (1989) based on this reconstruction, designate the lectotype and 4 paralectotypes from "Palermo, Oreto-Genist".

\section{Acicula hierae n. sp. (Figs. 5-7)}

TyPe LOCALITy. Marettimo Islands (Egadi Islands, north-western Sicily, Italy).

TyPe MATERIAL. Holotype (MCZR-M-TYPE
00252): Italy, Sicily, Marettimo Island, Canalazzo, 3758'20'N 1203'33'”, 420 m, 22.IV.2018, legit R. Viviano (Fig. 4). Paratypes: Italy, Sicily, Marettimo Island, Case Romane, 37 $58^{\prime} 14^{\prime \prime} \mathrm{N}$ 12 ${ }^{\circ} 03$ '51'”E, 230/240 m, 28.VII.2015, 1 sh (CV); Carcaredda, $37^{\circ} 57^{\prime} 12^{\prime \prime} \mathrm{N} 12^{\circ} 04^{\prime} 40^{\prime \prime} \mathrm{E}, 140 / 160 \mathrm{~m}$, 24.I.2016, 2 sh (CV); Carcaredda, 3757'16”N 12 ${ }^{\circ} 04^{\prime} 30^{\prime \prime} \mathrm{E}, 200 \mathrm{~m}, 10 . \mathrm{III} .2019,3$ sh (CR); Canalazzo, $37^{\circ} 58^{\prime} 20^{\prime \prime} \mathrm{N}, 12^{\circ} 03^{\prime} 33^{\prime \prime} \mathrm{E}, 426 \mathrm{~m}$, 24.I.2016, 1 sh (CL 16417); trail above Case Romane, 37 58'14.3'N 12॰03'39.7'”, 318/350 m, 22.IV.2018, 1 sh (CV); Canalazzo, 3758'20”N $12^{\circ} 03^{\prime} 33^{\prime \prime} \mathrm{E}, 420 \mathrm{~m}, 22 . \mathrm{IV} .2018,2 \mathrm{sh}$ (CV); trail to punta Ansini, 37 $58^{\prime} 06^{\prime \prime} \mathrm{N} 12^{\circ} 03^{\prime} 44.7^{\prime \prime} \mathrm{E}, 375 \mathrm{~m}$, 08.III.2019, 1 sh (CV); surroundings of Semaforo north slope, $37^{\circ} 57^{\prime} 37^{\prime} \mathrm{N} 12^{\circ} 03^{\prime} 41^{\prime}$ 'E, 380/400 m, 08.III.2019, 1 sh juv. (CV); surroundings of Semaforo south slope, $37^{\circ} 57^{\prime} 56^{\prime \prime} \mathrm{N} 12^{\circ} 03$ ' $42^{\prime \prime} \mathrm{E}, 430$ m, 08.III.2019, 1 sh (CR); idem, 3757'56”N 1203'42'E, 430 m, 08.III.2019, 1 sh (CR); Pizzo Madonnuzza, north slopes, 3759'19.6”N 12 ${ }^{\circ} 03$ '26’'E, 225 m, 09.III.2019, 1 sh juv. (CV); Case Romane, $37^{\circ} 58^{\prime} 14^{\prime \prime} \mathrm{N} 12^{\circ} 03^{\prime} 51^{\prime \prime} \mathrm{E}, 230 / 240$

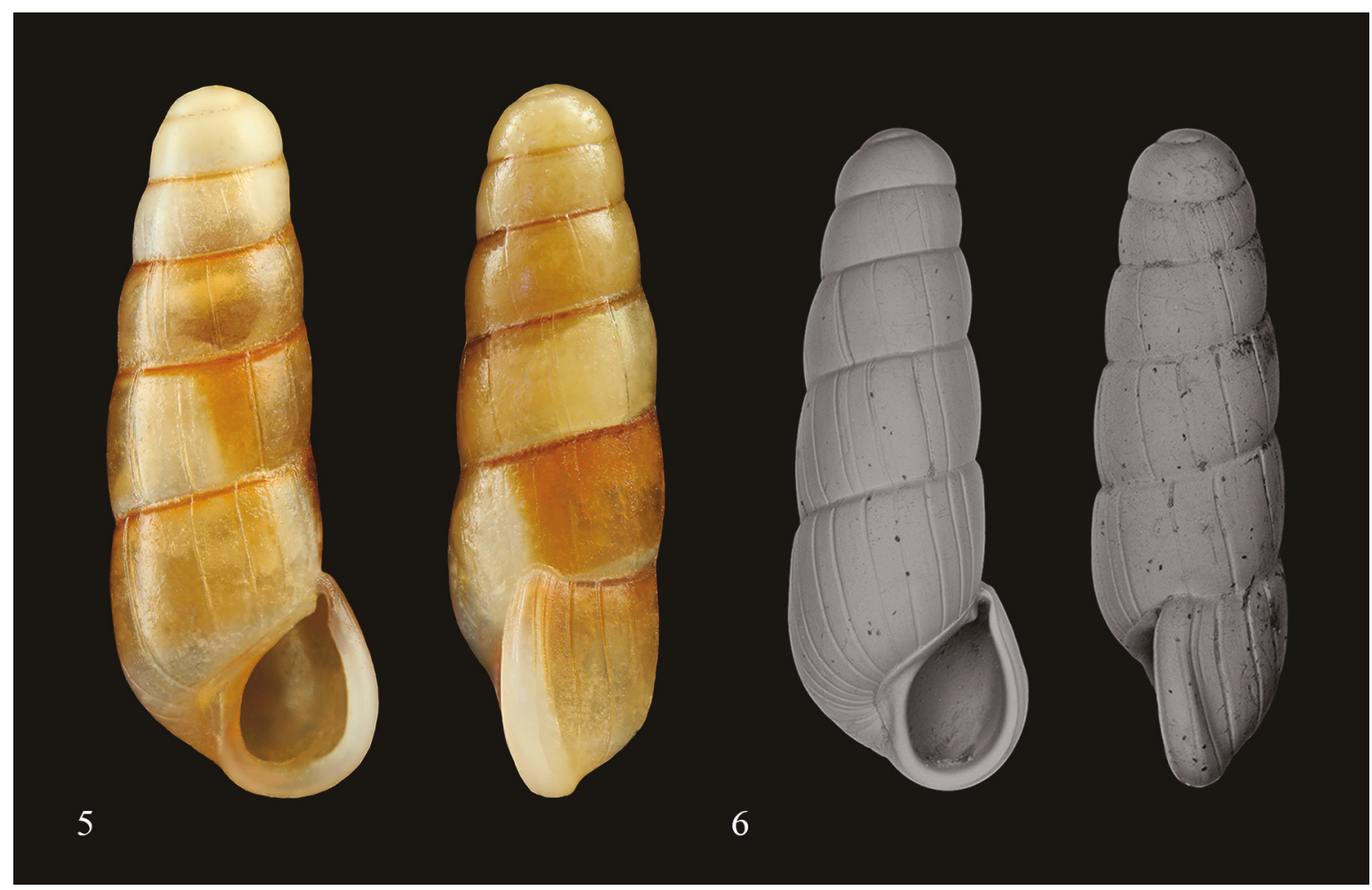

Figure 5. Acicula hierae n. sp., holotype: Italy, Sicily, Marettimo Island, Punta Campana, H: 4 mm, with soft part. Figure 6. Acicula hierae n. sp., paratype: Italy, Sicily, Marettimo Island, Carcaredda, H: 3.7 mm, SEM photo. 
m, 09.III.2019, 2 sh (CMS 5220/2); Carcaredda, 3757'16”N 1204'30”'E, 200 m, 10.III.2019, 3 sh (CR) (Fig. 6); Punta Campana, eastern slopes, 3758'22'N 12 03'27'”E, 490-520 m, 25.VIII.2020, 1 sh, legit R. Viviano (CV); Punta Campana, eastern slopes, base of a rocky wall, $37^{\circ} 58^{\prime} 21^{\prime \prime} \mathrm{N}$ 1203'25'E, 540 m, 25.VIII.2020, 3 sh, legit R. Viviano $(\mathrm{CV})$.

DiAgnosis. Conic-subcylindrical shell, with obtuse apex, well developed angular tooth and parietal callus; the upper part of the peristome forms a short canal with the angular tooth. External peristomal varix raised, rounded, delimited anteriorly and posteriorly by simple line, in lateral view narrower in the upper part and wider in the lower one; 5-5 $1 / 2$ whorls, last whorl $47-50 \%$ of shell height;12-16 spaced radial grooves on penultimate whorl.

Description of holotype. Shell (Fig. 5) dextral, small, little elongate, conic-subcylindrical, with obtuse apex, glassy and transparent, light brown in color with a thin subsutural darker brown band. Spire consisting of $5 \frac{1}{2}$ slightly convex whorls. Last whorl $50 \%$ of shell height, sutures shallow. External surface of teleoconch smooth, with irregularly spaced radial grooves, 14 in penultimate whorl. Aperture oval-pyriform; thickened peristome, rounded on the columellar side; upper and lower vertices joined by thick parietal callus; well developed angular tooth; the upper part of the peristome forms a short canal with the angular tooth. External peristomal varix raised, rounded, and delimited anteriorly and posteriorly by simple line, in lateral view it is narrower in the upper part, wider in the lower one; Umbilicus closed. H: $4 \mathrm{~mm}, \mathrm{D}: 1.25$ mm, LWH: $1.9 \mathrm{~mm}$.

Operculum H: $0.8 \mathrm{~mm}$, D: $0.6 \mathrm{~mm}$; dropshaped, very thin, transparent, sand-yellow in colour, paucispiral with semi-central nucleus; outer face with about 9 growth lines; smooth inner face, with muscle attachment area comma-shaped.

Body whitish; black round pupils and little black bacillus-shaped spots at the base of the tentacles; internal organs withish.

VARIABILITY. The paratypes do not show substantial morphological differences with the holotype: H: 3.3-4 mm, mean $3.8 \mathrm{~mm}$, D: $1.2-1.3 \mathrm{~mm}$; spire of $5-51 / 2$ whorls; last whorl $47-50 \%$ of shell height, 13-19 radial grooves in penultimate whorl.
ETyMology. The new species is named after "Hiera Nesos" (= Sacred Island) ancient name, first Greek and then Latin, of Marettimo island.

Distribution AND Biology. Acicula hierae n. sp. is until now known only from the type locality Marettimo Island (Fig. 1).

It occurs in natural habitats with Mediterranean maquis (mainly Salvia rosmarinus Spenn., Erica multiflora L., Cistus spp, Euphorbia dendroides L., 1753, Pistacia lentiscus L.) and oaks woods.

It lives in the crevices of dolomitic rocks, under stones and underground environments.

STATUS AND CONSERVATION. The restricted distribution makes $A$. hierae n. sp. "Vulnerable", according to the Categories and Criteria of the IUCN Red List of Threatened Species (IUCN, 2020).

Comparative nOtes. Acicula hierae n. sp. differs from the geographically closest Acicula species, $A$. benoiti from Sicily, in its lower height (3.3-4 mm for $A$. hierae n. sp., 3-4.7 mm for $A$. benoiti) lower height-to-width ratio (2.9 for $A$. $h i$ erae n. sp., 3.3 for $A$. benoiti), the highest last whorl (47-50\% of the total height in $A$. hierae n. sp., 22 $27 \%$ in $A$. benoiti), lower number of whorls (5-5 $1 / 2$ in $A$. hierae n. sp., $5 \frac{1}{2}-71 / 2$ in $A$. benoiti), canal between the angular tooth and the upper edge of the peristome, more developed in A. hierae n. sp.; external peristomal varix more raised, and delimited anteriorly and posteriorly, while in $A$. benoiti more like a swelling, without clear demarcation in the basal part; in lateral view the esternal peristoma varix is wider in the lower part in A. hierae n. sp. while in $A$. benoiti the same width troughout its lenght is shown.

From the North African Acicula species, A. hierae n. sp. is well differentiated from $A$. letourneuxi (Bourguignat, 1864) (see Boeters et al., 1989: 59, Fig. 59) while it is more similar to A. algerensis Gittenberger et Boeters, 1977 (Algeria and Morocco) and to A. lallemanti (Bourguignat, 1864) (Algeria, Tunisia, Libya). The new species differs from $A$. algerensis and $A$. lallemanti for the more developed angular tooth and external peristomial varix, and for the greater height of the last whorl. In addition, it differs from $A$. lallemanti in a more compact shape of the shell and the lower number of furrows on the penultimate whorl (24-34 in A. lallemanti) (see also Gittenberger \& Boeters, 1977b; Boeters et al., 1989). 


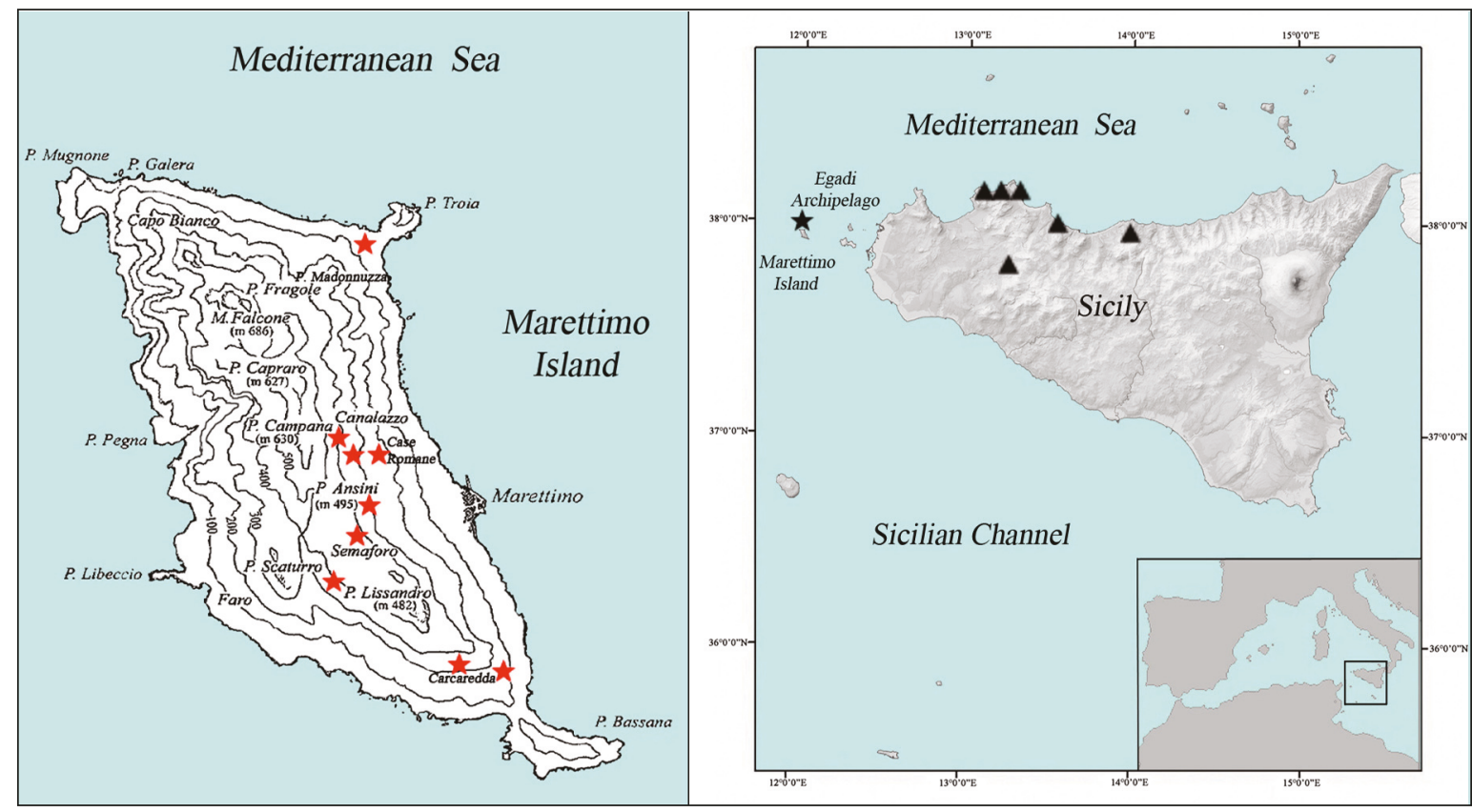

Figure 7. Distribution map of Acicula benoiti (triangles) and A. hierae n. sp. (stars) according to the examined material.

Acicula szigethyannae Subai, 1977 (Italy: from Liguria to Calabria) differs mainly from $A$. hierae n. sp. for the subquadrangular aperture, less developed angular tooth, external peristomal varix flat and crossed by furrows, the greater number of furrows (19-27) on the penultimate whorl (Subai, 1977; Eikenboom, 1998; Feher, 2013).

Fiorentino et al. (2004) reports $A$. benoiti for the Marettimo island, but in our samples only A. hierae n. sp. has been found.

Among the uncertain taxa described for Marettimo, the systematic position of Caecilianella maretima Benoit, 1882 remains to be clarified. The Sicilian author (Benoit, 1882) provides a very simple description, however, based on morphological affinities, he adds this new species in the Cecilioides-Hohenwarthiana species group. In the same work the Sicilian Acicula species is attributed to the genus Acme (Benoit, 1882 sub A. lineata $=A$. benoiti). Alzona (1971) reports "maretima Benoit, 1882 " among the dubious species belonging to the genus Hohenwarthiana Bourguignat, 1864.

\section{CONCLUSIONS}

Acicula hierae n. sp. is added to the endemic land molluscs of Marettimo, that include five other species: Siciliaria scarificata (L. Pfeiffer, 1856); Oxychilus (Hyalofusca) denatale (L. Pfeiffer, 1856); Schileykiella bodoni Cianfanelli, Manganelli et Giusti, 2004; Cernuella (Xeroamanda) depressior (Benoit, 1859); Marmorana insularis (Benoit, 1857).

\section{ACKNOWLEDGEMENTS}

We are grateful to Gianbattista Nardi (Brescia, Italy) and Massimo Appolloni (Museo Civico di Zoologia, Rome, Italy). Thanks are also due to Prof. Rossana Sanfilippo and Mr. Alfio Viola (University of Catania, Italy), who allowed the realisation of SEM photographs.

\section{REFERENCES}

Alzona C., 1971. Malacofauna Italica. Catalogo e bibliografia dei molluschi viventi, terrestre e d'acqua dolce. Atti della Società di Scienze Naturali e del Museo Civico di Storia naturale di Milano, 111: 1433.

Bank R.A. \& Ramos M., 2017. Fauna Europaea: Acicula W. Hartmann, 1821. version 2017.06, https://faunaeu.org Accessed at https://fauna-eu.org/cdm_data- 
portal/taxon/59391818-c533-4885-a869-580dfef 94bce on 2020.04.10

Benoit L., 1857-1862. Illustrazione sistematica critica iconografica de' testacei estramarini della Sicilia Ulteriore e delle isole circostanti. Gaetano Nobile, Napoli, 248 pp., 11 Pls. Quaderno 1: pp. i-xvi, 1-52, Pls.1-2 (1857); Quaderno 2: pp. 53-116, Pls. 3-4 (1857); Quaderno 3: pp. 117-180, Pls. 5-6 (1859); Quaderno 4: pp. 181-248, Pls. 7-8 (1862).

Benoit L., 1875. Catalogo delle conchiglie terrestri e fluviatili della Sicilia e delle Isole circostanti. Bullettino della Società Malacologica italiana, 1: 129-163.

Benoit L., 1882. Nuovo catalogo delle conchiglie terrestri e fluviatili della Sicilia o continuazione alla illustrazione sistematica critica iconografica de' testacei estramarini della Sicilia Ulteriore e delle isole circostanti. D'Amico, Messina, VI+176 pp.

Bodon M., Favilli L., Giannuzzi Savelli R., Giovine F., Giusti F., Manganelli G., Melone G., Oliverio M., Sabelli B. \& Spada G., 1995. Gastropoda Prosobranchia, Heterobranchia Heterostropha. In: Minelli A., Ruffo S. \& La Posta S. (Ed.), Checklist delle specie della fauna italiana, 14. Edizioni Calderini, Bologna, 60 pp.

Boeters H.D., Gittenberger E. \& Subai P., 1989. Die Aciculidae (Mollusca, Gastropoda, Prosobranchia). Zoologische Verhandelingen, 252: 1-234.

Bourguignat J. R., 1864. Malacologie de l'Algérie ou histoire naturelle des animaux mollusques terrestres et fluviatiles recueillis jusqu'à ce jour dans nos possessions du nord de l'Afrique. Tome second. - pp. [1], 1-380, [1-27], 1-4, Pls. I-XXVII [= 1-27]. Paris, Alger. (Challamel Ainé, Bastide).

Calcara P., 1845. Esposizione dei molluschi terrestri e fluviatili dei dintorni di Palermo. Atti della Accademia di Scienze e Lettere di Palermo, 1: 1-44, 1 Pl.

Cossignani T. \& Cossignani V., 1995. Atlante delle conchiglie terrestri e dulciacquicole italiane. L'Informatore Piceno, Ancona, 208 pp.

Cossignani T. \& Cossignani V., 2020. Atlante delle conchiglie terrestri e dulciacquicole italiane (nuova edizione 2020). L'Informatore Piceno, Ancona, 228 pp.

Cuttelod A., Seddon M. \& Neubert E., 2011. European Red List of Non-marine Molluscs. Luxembourg: Publications Office of the European Union. Publications Office of the European Union, http://bookshop.europa.eu IUCN Publications Services, www.iucn.org/publications

De Gregorio A., 1895. Appunti su talune conchiglie estramarine di Sicilia viventi e fossili con la spiegazione delle tavole dell'opera di Benoit. Il Naturalista siciliano, 14: 183-212.

Eikenboom J., 1998. New data on the distribution of Platyla stussineri (Boettger, 1884) and Acicula szigethyannae Subai, 1977 (Prosobranchia, Aciculidae) in Italy. Bollettino Malacologico, 33: 141-142.

Feher Z., 2013. Acicula szigethyannae. In: IUCN 2013. IUCN Red List of Threatened Species. Version 2013.2. <www.iucnredlist.org>. Downloaded on 16 March 2014. http://www.iucnredlist.org/details/summary/157062/0

Fiorentino V., Cianfanelli S., Manganelli G. \& Giusti F., 2004. I molluschi non marini delle isole Egadi (Canale di Sicilia): biodiversità e conservazione. Poster XIV congresso nazionale Società Italiana di Ecologia, Siena.

Gittenberger E. \& Boeters H.D., 1977a. Acicula (A.) lineate (Draparnaud) und A. (A.) lineolata (Pini) (Prosobranchia, Aciculidae). Zoologische mededelingen, 52: 217-222, 1 P1.

Gittenberger E. \& Boeters H.D., 1977b. Some remarks on Acicula s.s. (Prosobranchia Rissoacea). Journal of Conchology, 29: 125-128.

Hesse P., 1920. Einige Bemerkungen über die Familie Acmidae nebst Verseichnis der Arten. Archiv für Molluskenkunde, 52: 78-89.

IUCN, 2020. The IUCN Red List of Threatened Species. Version 2020-2. https://www.iucnredlist.org. Downloaded on 09 July 2020.

Kobelt W., 1881. Catalog der im europäischen Faunengebiet lebenden Binnen-Conchylien. 2. Auflage. Fischer, Cassel, 294 pp.

Kobelt W., 1896. Iconographie der Land- \& SüsswasserMollusken mit vorzüglicher Berücksichtigung der europäischen noch nicht abgebildeten Arten von E. A. Rossmässler. Wiesbaden, Kreidel, Neue Folge. 7: 1107 Pls., 181-210.

Kobelt W., 1898. Studien zur Zoogeographie. II. Die Fauna der meridionalen Sub-Region. Wiesbaden, Kreidel, 1-10 + 1-368 pp.

Kobelt W., 1908. Synopsis der Mollusca Pneumonopoma Opistophtalmi (Acmidae, Geomelanidae, Truncatellidae). Jahrbücher des Nassauischen vereins für naturkunde, 61: 156-220.

Kobelt W. \& Möllendorff O. von, 1897. Catalog der gegenwärtig lebend bekannten Pneumonopomen. Nachrichtsblatt der Deutschen Malakozoologischen Gesellschaft, 29: 73-88.

Liberto F., Giglio S., Reitano A., Colomba M.S. \& Sparacio I., 2010. Molluschi terrestri e dulciacquicoli di Sicilia della collezione F. Minà Palumbo di Castelbuono. Monografie Naturalistiche, 2. Edizioni Danaus, Palermo, $136 \mathrm{pp}$.

MolluscaBase, 2020. MolluscaBase. Acicula W. Hartmann, 1821. Accessed at: http://www.molluscabase. org/aphia.php? $\mathrm{p}=$ taxdetails\&id=866691 on 2020-0410.

Neubert E., Seddon M.B., Allen D.J., Arrébola J., Backeljau T., Balashov I., Bank R., Cameron R., de Frias 
Martins A.M., De Mattia W., Dedov I., Duda M., Falkner G., Falkner M., Fehér Z., Gargominy O., Georgiev D., Giusti F., Gómez Moliner B.J., Groh K., Ibáñez M., Kappes H., Manganelli G., Martínez-Ortí A., Nardi G., Neiber M.T., Páll-Gergely B., Parmakelis A., Prié V., Reischütz A., Reischütz P.L., Rowson B., Rüetschi J., Slapnik R., Son, M., Štamol V., Teixeira D., Triantis K., Vardinoyannis K., von Proschwitz T. \& Walther F., 2019. Supplementary Material to the European Red List of terrestrial molluscs. Cambridge, UK: IUCN. Available at: https:// portals.iucn.org/library/node/48439

Paladilhe A., 1868. Nouvelle miscellanées malacologiques. Monographie du genre Acme. 65-100, Pl. 4.

Paulucci M., 1879. Escursione scientifica nella Calabria 1877-78. Fauna malacologica. specie terrestri e fluviatili. Bocca, Firenze, 223 pp., 9 Pls.

Paulucci M., 1881. Fauna Italiana. Comunicazioni malacologiche, articolo settimo, Descrizione di una nuova specie del genere Acme. Bullettino della società italiana di malacologia, 7: 221-225.

Pfeiffer L., 1876. Monographia pneumonopomorum viventium, accedente fossilium enumeratione. Supplementum tertium, monographiae auriculaceorum parte secunda auctum. Cassellis, Th. Fischer, 1-10+ $1-479 \mathrm{pp}$.

Reitano A., Liberto F., Sparacio I. \& Giglio S., 2009. I molluschi terrestri della R.N.I. "Grotta Palombara" (Melilli, Sicilia sud-orientale) (Gastropoda Architae- nioglossa, Neotaenioglossa, Stylommatophora). Il Naturalista siciliano, 33: 177-205.

Reitano A., Liberto F., Giglio S., Grasso R. \& Spena M. T., 2012. Terrestrial molluscs from the R.N.I. "Grotta Conza" (Palermo, Sicily) (Gastropoda Architaenioglossa Pulmonata). Biodiversity Journal, 3: 555570.

Schacko G., 1875. Radula und Kiefer des Genus Acme. Jahrbücher der Deutschen Malakozoologischen Gesellschaft, 2: 137-152, Pls. 4-5.

Subai P., 1977. Über italienische Acicula-Arten (Gastropoda: Prosobranchia). Archiv für Molluskenkunde, 108: 37-43.

Welter-Schultes F.W., 2012. European non-marine molluscs, a guide for species identification: A1-A3, 1679, Q1-Q78. Planet Poster Editions, Göttingen.

Westerlund C.A., 1871. Fauna molluscorum terrestrium et fluviatilium Sveciæ, Norvegiæ et Daniæ. Sveriges, Norges och Danmarks land- och sötvattenmollusker. I. Landmolluskerna. Stockholm, Bonnier, $1-5+1-296 \mathrm{pp}$.

Westerlund C.A., 1885. Fauna der in der paläarctischen Region (Europa, Kaukasien, Sibirien, Turan, Persien, Kurdistan, Armenien, Mesopotamien, Kleinasien, Syrien, Arabien, Egypten, Tripolis, Tunesien, Algerien und Marocco) lebenden Binnenconchylien. V. Fam. Succinidæ, Auriculidæ, Limnæidæ, Cyclostomidæ \& Hydrocenidæ. Lund, Håkan, Ohlsson, 1-135 $+1-14 \mathrm{pp}$. 
. 